\title{
CD68 Antigen Expression by Human Retinal Pigment Epithelial Cells
}

\author{
SUSAN G. ELNER ${ }^{*}$, VICTOR M. ELNER ${ }^{a, b *}$, JARL C. NIELSEN ${ }^{c}$, ELISE TORCZYNSKIc, \\ RILEY YUd AND WILBUR A. FRANKLIN ${ }^{e}$ \\ Departments of ${ }^{a}$ Ophthalmology and ${ }^{b}$ Pathology, University of Michigan, Ann Arbor, MI 48105, \\ Departments of 'Ophthalmology and 'Neurology, University of Chicago, Chicago, IL 60637, and \\ Department of ${ }^{~ P a t h o l o g y, ~ U n i v e r s i t y ~ o f ~ C o l o r a d o, ~ D e n v e r, ~ C O ~ 80262, ~ U . S . A . ~}$
}

(Received New York 14 June 1991 and accepted in revised form 28 August 1991)

\begin{abstract}
Although a primary role of the retinal pigment epithelium (RPE) is the phagocytosis of aged outer segment membranes. the RPE may also phagocytize particulates via several specific receptors that are characteristically present on mononuclear phagocytes of bone marrow origin. In recent immunophenotypic studies, CD68 monoclonal antibodies (mAb) have been shown to react selectively with a specific $110 \mathrm{kDa}$ cytoplasmic glycoprotein present in mononuclear phagocytes from various sources. Designated as anti-macrophage antibodies that react with this macrophage-associated antigen, CD68 antibodies are now widely used for immunohistochemical identification of mononuclear phagocytes. Using a panel of $\mathrm{CD} 68 \mathrm{mAb}(\mathrm{KP} 1$, EBM11, Ki-M6, Y1/82A, and $\mathrm{Y} 2 / 131)$ we performed immunohistochemistry on three cytospin preparations of freshly isolated human RPE cells, three primary human RPE cultures, and 12 human RPE cell lines maintained in culture for up to 40 passages. Cytospin preparations of freshly isolated RPE cells demonstrated heavy reactivity in $5 \%$ of cells. Five- to 7 -day-old primary RPE cultures exhibited uniform, heavy staining of all cells. Strong immunohistochemical reactivity persisted in all 12 cell lines at various passages up to and including passage 40 . Stimulation of cultured RPE cells with interferon-gamma $\left(100 \mathrm{U} \mathrm{ml}^{-1}\right)$ for 24 and $48 \mathrm{hr}$ did not produce observable differences in CD68 staining. RPE cells failed to stain when control $\mathrm{mAb}$ or mouse serum were substituted for the primary antibody. The constitutive expression of CD68 by neuroectodermally-derived RPE cells extends their immunophenotypic similarities with mesenchymally-derived mononuclear phagocytes and provides an additional antigenic marker to identify RPE cells in vitro.

Key words: retinal pigment epithelium: CD68; monoclonal antibodies; immunohistochemistry; macrophage-associated antigen.
\end{abstract}

\section{Introduction}

A vital role of the retinal pigment epithelium (RPE) is the ongoing phagocytosis of aged, light-damaged outer segment material shed from the tips of photoreceptors on a diurnal basis. The actively phagocytic RPE also possesses many mononuclear/macrophage features, including the presence of receptors for $\mathrm{Fc}$ and $\mathrm{C} 3 \mathrm{bi}$ (Elner et al., 1981) and mannose 6-phosphate (McLaughlin. Tarnowski and Shepherd, 1987) as well as scavenger receptors which mediate acetylated lipoprotein uptake and degradation (Elner, Davis and Elner, 1984; Hayes et al., 1989). In immunophenotypic studies on cultured human RPE cells, we confirmed the presence of RPE C3bi receptors (CD$11 \mathrm{~b} / \mathrm{CD} 18$; Mac 1) and reported RPE expression of other antigens typically present on monocyte/ macrophages, including HLA-DR, CD11c, and CD14 (Nielsen et al., 1987; Elner et al., 1989; Pavilack et al., 1990).

At the Third Workshop on Leucocyte Differentiation Antigens, five monoclonal antibodies (mAb), EBM11, Ki-M6, Y1/82A, Y2/131, and 24, which reacted with the majority of tissue macrophages in sections of human tissue, were originally grouped together due to their immunoreactivity with macrophages. They were later found, with the exception of $\mathrm{mAb} 24$, to react with different antigenic sites of the same $110 \mathrm{kDa}$ glycoprotein and were designated $\mathrm{CD} 68 \mathrm{mAb}$ at the Fourth International Conference on Human Leucocyte Differentiation Antigens (Vienna, 1989). CD68 mAb are now used as probes to detect mononuclear phagocytes by virtue of their reactivity with the macrophage-associated antigen (CD68 antigen) (Micklem et al., 1989).

Based on receptor and immunophenotypic similarities between mononuclear phagocytes and RPE cells, we attempted to demonstrate the presence of CD68 antigen on human RPE cells. Using a panel of CD68 mAb, cultured RPE cells were found to express high constitutive levels of CD68 antigen which was also present in a small percentage of freshly isolated RPE cells. 
TABLE I

CD68 antigen expression by human RPE cells

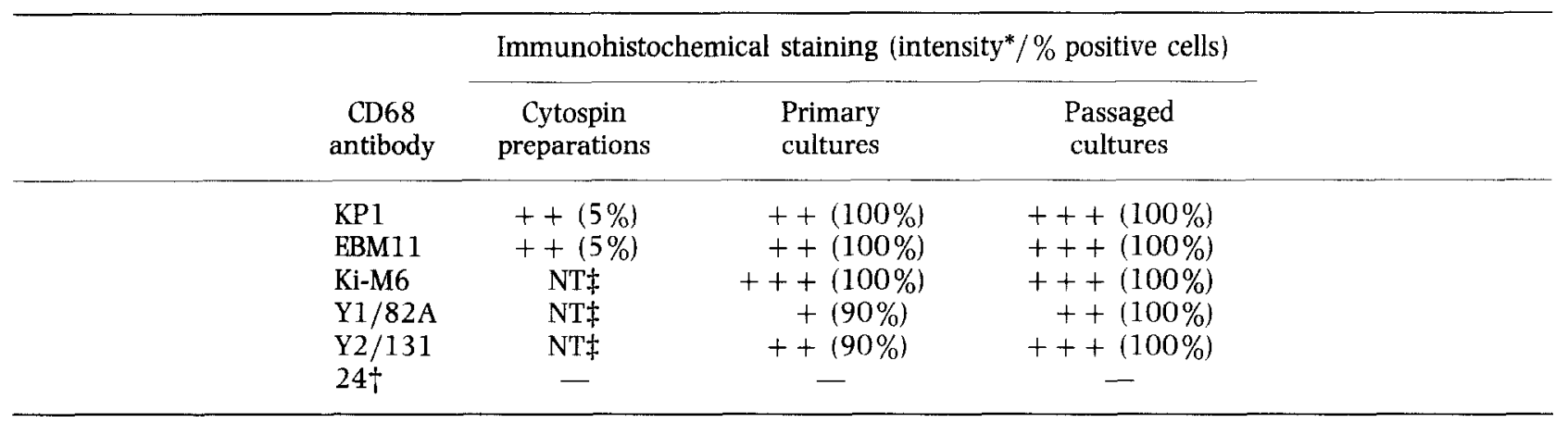

* Indicates intensity of majority of cells: +++ , intense; ++ , moderate; + , weak; - , no observable staining.

+ No longer designated CD68; reacts with antigen distinct from CD68 (Hogg and Selvendran, 1985).

$\ddagger$ Not tested.

\section{Materials and Methods}

\section{Human RPE Cell Cultures and Primary RPE Cell Preparations}

Human RPE cells were isolated from donor eyes within $24 \mathrm{hr}$ of death using a modification of the method of Edwards (1982) as previously described (Elner et al., 1990). In brief, the sensory retina was gently separated from the RPE monolayer which was then trypsinized $(0.25 \%)$ for 30 to $40 \mathrm{~min}$ from Bruch's membrane into serum-free DMEM containing $0.02 \mathrm{mg} \mathrm{ml}^{-1}$ DNase I (Sigma Chemical Co., St Louis, $\mathrm{MO})$. Following centrifugation and resuspension in Dulbecco's Modified Essential Medium (DMEM) containing $15 \%$ fetal bovine serum (FBS), penicillin $G$ (100 $\left.\mathrm{U} \mathrm{ml}^{-1}\right)$, streptomycin sulfate $\left(100 \mu \mathrm{g} \mathrm{ml}^{-1}\right)$, and amphotericin B $\left(2.5 \mu \mathrm{g} \mathrm{ml}^{-1}\right)$ (Gibco Inc., Grand Island, NY), the RPE cells were seeded into $25 \mathrm{~cm}^{2}$ Falcon Primaria flasks (Becton-Dickinson Inc., Lincoln Park, NJ) to inhibit fibroblast growth. Cells were passaged by trypsinization. For immunohistochemical staining, $5 \times 10^{4} \mathrm{RPE}$ cells were plated onto sterile glass coverslips, allowed to adhere to the coverslips for $2 \mathrm{hr}$, and flooded with complete media. After 5 days, media covering each coverslip was exchanged for identical media containing either interferon-gamma (IFN- $\gamma$ ) or no stimulant.

To insure that RPE staining for $\mathrm{CD} 68$ was reproducible, experiments were repeated using 12 human RPE cell lines each of which displayed distinctive morphologic features typical for RPE cells. To exclude the possibility of contaminating cell types, the RPE cultures were examined using various markers. The RPE monolayers exhibited uniform immunohistochemical staining for fibronectin, laminin, and type IV collagen in a chickenwire distribution, characteristic for these epithelial cells (Campochiaro, Jerdan and Glaser, 1986). The RPE cells also showed avid and uniform incorporation of fluorescently-labeled acetylated-low density lipoproteins (Elner et al., 1984 ; Elner.
1986), and failed to stain for factor VIII antigen or with Ulex europaeus I lectin (Vector Laboratories, Burlingame, CA). Furthermore, RPE cells derived from three of the passaged cell lines produced IL-8 when exposed to $\Pi-1 \beta$ and TNF- $\alpha$, but failed to do so in response to lipopolysaccharide (Elner et al., 1990), a known stimulant of $\Pi-8$ in vascular endothelial cells (Strieter et al., 1989) and mononuclear phagocytes (Strieter et al., 1990). Taken together these studies indicate that our RPE cell cultures were pure and uniform and that the results obtained were not due to contaminating cell types such as macrophages, vascular endothelium, or fibroblasts.

Three primary human RPE cell cultures from three separate donors were used for CD68 immunohistochemical staining. The RPE cell lines established from these cultures were subsequently stained at sequential passages $2,4,8$, and 12 for CD68 antigen expression. At least three different passages of each of nine other RPE cell lines passaged 2, 4, 5, 6, 8, 12, 20, 25 , or 40 times were also used for $\operatorname{CD} 68$ immunostaining. To determine the effect of IFN- $\gamma$ on CD68 expression, three separate experiments on each of three RPE cell lines (passages $2,4,5$ ) were performed. In these experiments, RPE cells exposed to human rIFN- $\gamma\left(100 \mathrm{U} \mathrm{ml}^{-1}\right.$; Collaborative Research Inc., Bedford, MA) or left unstimulated for 24 or $48 \mathrm{hr}$ were stained simultaneously for CD68 antigen expression. In all experiments, sister cultures containing near confluent cells that had been seeded at the same time and density from the same parent culture were used.

To confirm CD68 immunostaining of freshly-isolated RPE cells, cytospin preparations were used. RPE cells were gently scraped from Bruch's membrane into DMEM, immediately placed in a cytospin centrifuge (Shandon, Cytospin II, Sewickley, PA) for $5 \mathrm{~min}$ at $1000 \mathrm{rpm}$, fixed for $5 \mathrm{~min}$ in ice-cold acetone or $4 \%$ buffered paraformaldehyde, and permeabilized for $10 \mathrm{~min}$ in phosphate-buffered saline containing $0.01 \%$ Triton X-100 to yield glass slides with adherent, 


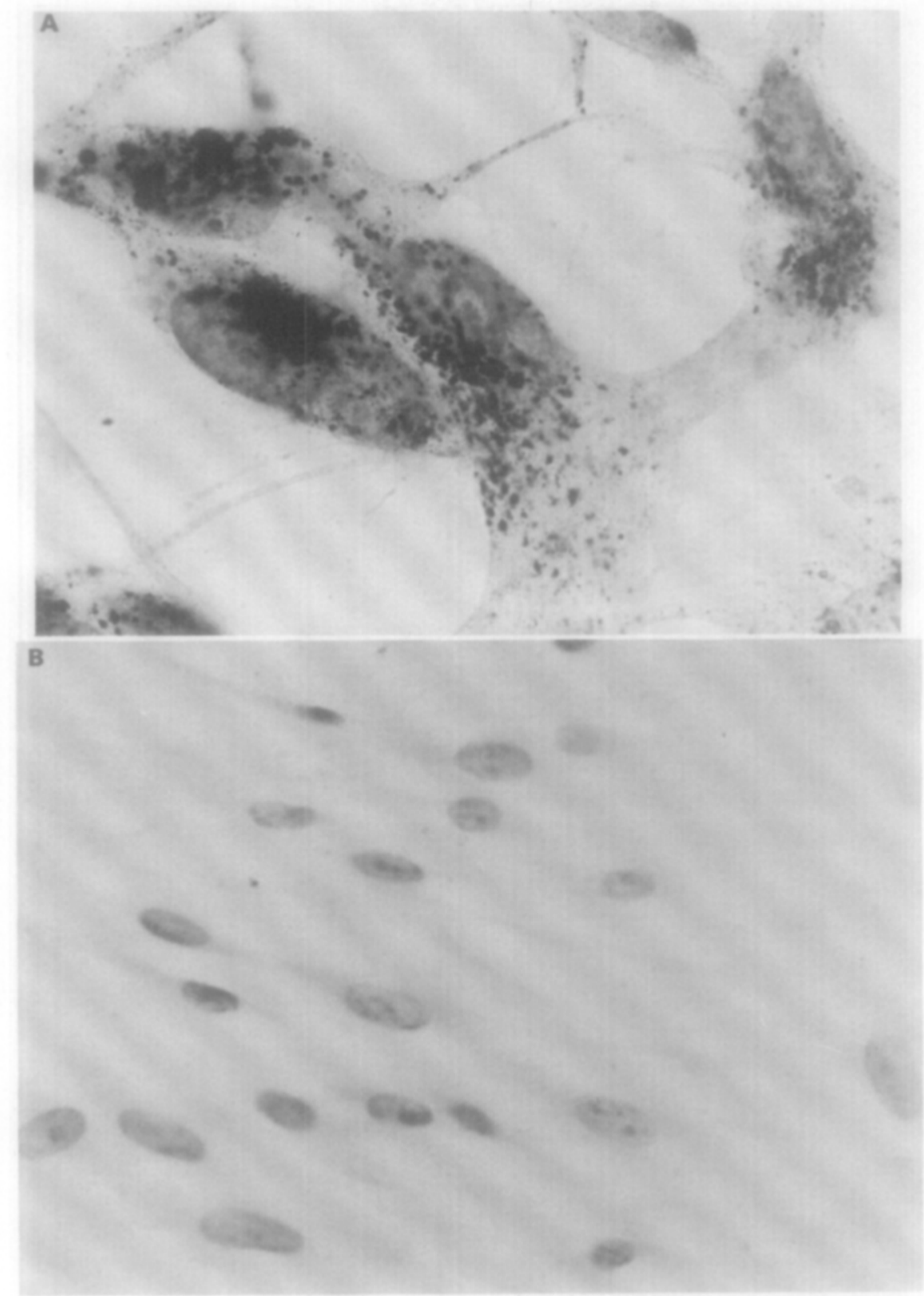

FIG. 1. CD68 staining of primary human RPE cell cultures. A, RPE cells in primary cultures stained with Y2/131 CD68 mAb. All cells contain heavy granular cytoplasmic reaction product, predominantly in a perinuclear pattern. Some of the RPE cells contained visible melanin granules. Original magnification: $\times 1000$; immunoalkaline phosphatase-hematoxylin. B. Cultured human foreskin fibroblasts incubated using same primary antibody fail to show any visible stain. Original magnification: $\times$ 400; immunoalkaline phosphatase-hematoxylin.

intact, densely pigmented RPE cells containing characteristic and easily recognizable pigment granules.

\section{Immunohistochemical Staining for RPE Cell CD68 Antigen}

To detect CD68 antigen in human RPE cells, two immunohistochemical techniques were employed. Immunoperoxidase staining was performed on cultured RPE cells and freshly-isolated RPE cytospin preparations that were fixed in ice-cold $4 \%$ buffered paraformaldehyde for $5 \mathrm{~min}$ and permeabilized for 10 min. Endogenous peroxidase activity was blocked with $50 \%$ methanol containing $1.5 \% \mathrm{H}_{2} \mathrm{O}_{2}$ for $20 \mathrm{~min}$ and RPE cells were overlaid with $10 \%$ normal rabbit serum to block non-specific staining. Primary incubations were then performed using one of the following CD68 mAb: KP1, EBM11 (both 1:500 dilution of ascites, Dako Corp., Carpinteria, CA), Ki-M6, Y1/82A, and $\mathrm{Y} 2 / 131$ (all 1:100 dilution of ascites from the Third Workshop on Leucocyte Differentiation Antigens, Oxford, 1986) (McMichael, 1986). The cell preparations were then incubated sequentially with secondary biotinylated rabbit anti-mouse antibody (1:250 dilution; Dako), streptavidin-biotinylated horseradish peroxidase complexes (Dako), and a substrate solution containing 3-amino-3-ethyl-carbazole $\left(0.5 \mathrm{mg} \mathrm{m}^{-1}\right.$ : Sigma) and $0.01 \%$ hydrogen peroxide 


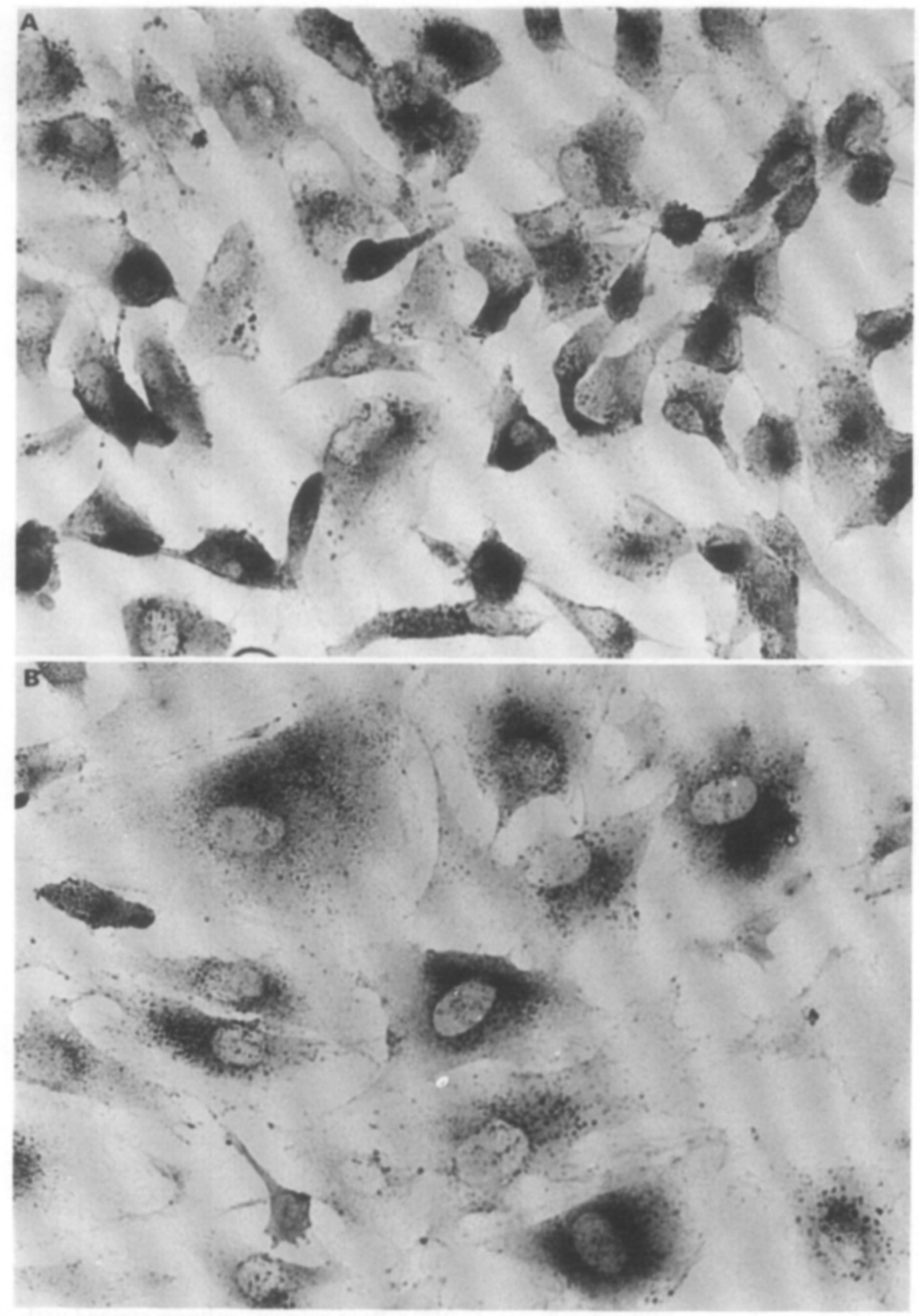

F1G. 2. For legend see facing page.

in $0 \cdot 1 \mathrm{~m}$ acetate buffer, $\mathrm{pH} 5 \cdot 2$. Positive staining resulted in a red-brown, reaction product.

For immunoalkaline phosphatase staining. cytospun and cultured RPE cells were fixed in ice-cold acetone for $10 \mathrm{~min}$. After the same blocking. primary, and secondary antibody incubations used for immunoperoxidase staining, RPE cells were overlaid with streptavidin-biotinylated alkaline phosphatase complexes (Dako) and developed with a substrate solution containing fast red TR salt $\left(3 \mathrm{mg} \mathrm{ml}^{-1}\right.$; Sigma), levamisole $\left(0.3 \mathrm{mg} \mathrm{ml}^{-1}\right.$; Sigma), and $\alpha$ naphthol-AS-MX-phosphate $\left(0.2 \mathrm{mg} \mathrm{ml}^{-1}\right.$; Sigma) to yield a red, granular reaction product.

Negative controls included substitution of primary CD68 mAb with normal mouse serum $(1: 2000$; Dako) or mAb 24 (1:100 dilution of ascites from the Third Workshop on Leucocyte Differentiation Anti- gens, Oxford, 1986) (Hogg and Selvendran, 1985) and To5 (CD35; $1: 100$; Dako) to unrelated antigens. Simultaneous immunohistochemical incubations of cultured human foreskin fibroblasts and human splenic macrophages using CD68 mAb served as negative and positive controls, respectively. Each antibody incubation was performed for $1 \mathrm{hr}$ at $37^{\circ} \mathrm{C}$. All preparations were counterstained with hematoxylin and mounted in Gel/Mount (Biomeda Corp., Foster City, CA).

To ascertain RPE CD68 immunoreactivity in situ. immunohistochemical staining was performed on $6 \mu \mathrm{m}$ frozen sections of surgically removed human eyes that were fixed for $10 \mathrm{~min}$ in either icé-cold acetone or $4 \%$ buffered formaldehyde and on deparaffinized, rehydrated $6 \mu \mathrm{m}$ sections of surgically removed eyes fixed in $4 \%$ buffered formaldehyde. 


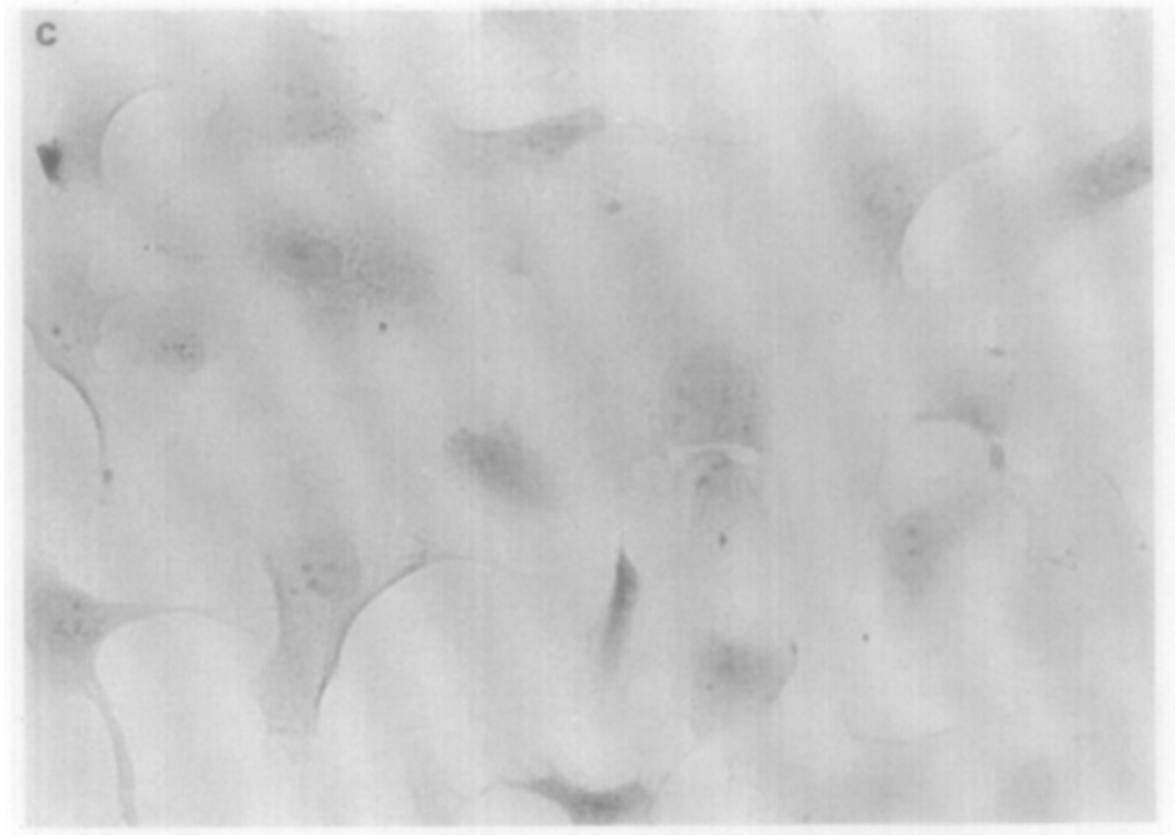

FIg. 2. Passaged human RPE cells stained with CD68 mAb. A, RPE cells in culture after 40 passages stain heavily with EBM11 CD68 mAb. Positive stain, seen in $100 \%$ of cells, is predominantly perinuclear. Original magnification: $\times 200$; immunoperoxidase-hematoxylin. B, Granular, perinuclear reaction product of similar intensity is present in fourth passage RPE cells stained using EBM1 1 CD68 mAb. Original magnification: $\times 400$; immunoperoxidase-hematoxylin. C, RPE cells in sister cultures did not stain when normal mouse serum was substituted for primary antibody. Original magnification: $x 400$; immunoperoxidase-hematoxylin.

Using KP1 and EMB11 mAb over concentrations ranging from $1: 500$ to $1: 10$, immunoperoxidase and immunoalkaline phosphatase staining were performed as described above. Positive controls included sections of normal human spleen prepared and stained in the same fashion.

\section{Analysis of Immunohistochemical Staining}

The stained cell preparations and tissue sections were examined by light microscopy and graded by three independent, masked observers. The degree of positive immunohistochemical staining was graded from 0 to +++ and the percentages of cells demonstrating positive immunohistochemical staining were noted for each preparation.

\section{Results}

All five CD68 mAbs stained $90-100 \%$ of the cells in the three primary human RPE cultures [Table I, Fig. 1(A)]. The majority of RPE cells in these preparations exhibited moderate or intense granular, cytoplasmic immunoalkaline phosphatase and immunoperoxidase staining using four of the five $\mathrm{CD}$ $68 \mathrm{mAbs}$ (Table I). Positive, albeit weaker, immunoreactivity was also present in the remaining RPE cells in all three primary cultures. No staining was observed when non-immune mouse serum or control mouse $\mathrm{mAb}$ were used as primary antibody. Simultaneous immunohistochemical assays on cultured primary and passaged human fibroblasts failed to demonstrate any staining with any of the CD68 mAbs [Fig. 1(B)], whereas virtually $100 \%$ of freshly isolated human splenic macrophages stained intensely using all CD68 mAbs (not shown).

As early as second passage, increased intensity of CD68 immunostaining was noted in all three RPE cell lines followed sequentially for passages $1,2,4,8$, and 12. The degree of increased intensity seen at early passages was maintained through all subsequent passages. Similar degrees of intense immunostaining were also observed and maintained in nine other passaged human RPE cell lines, regardless of passage, up to passage 40 . All of the passaged RPE cultures exhibited immunostaining of $100 \%$ of cells with each of the five CD68 mAbs (Table I). Intense immunohistochemical staining was observed in the majority of RPE cells with all remaining RPE cells in each preparation exhibiting lesser degrees of positive staining [Figs 2(A) and (B)]. The granular reaction product was located within the cytoplasm, primarily in a perinuclear distribution [Fig. 2(B)]. No observable increase in CD68 immunoreactivity was noted in any of three RPE cultures at either 4 th, 12 th, or 40 th passage after stimulation with IFN- $\gamma\left(100 \mathrm{U} \mathrm{ml}^{-1}\right)$ for either 24 or $48 \mathrm{hr}$. In all studies, no observable staining was present when sister cultures of human RPE cells were incubated with non-immune mouse serum [Fig. 2(C)] or CD35 mAb (not shown) as primary antibody. Of note. $24 \mathrm{mAb}$, now known to react with an antigen distinct from $\mathrm{CD} 68$, also failed to react with either the primary or passaged RPE cells (Table I). 


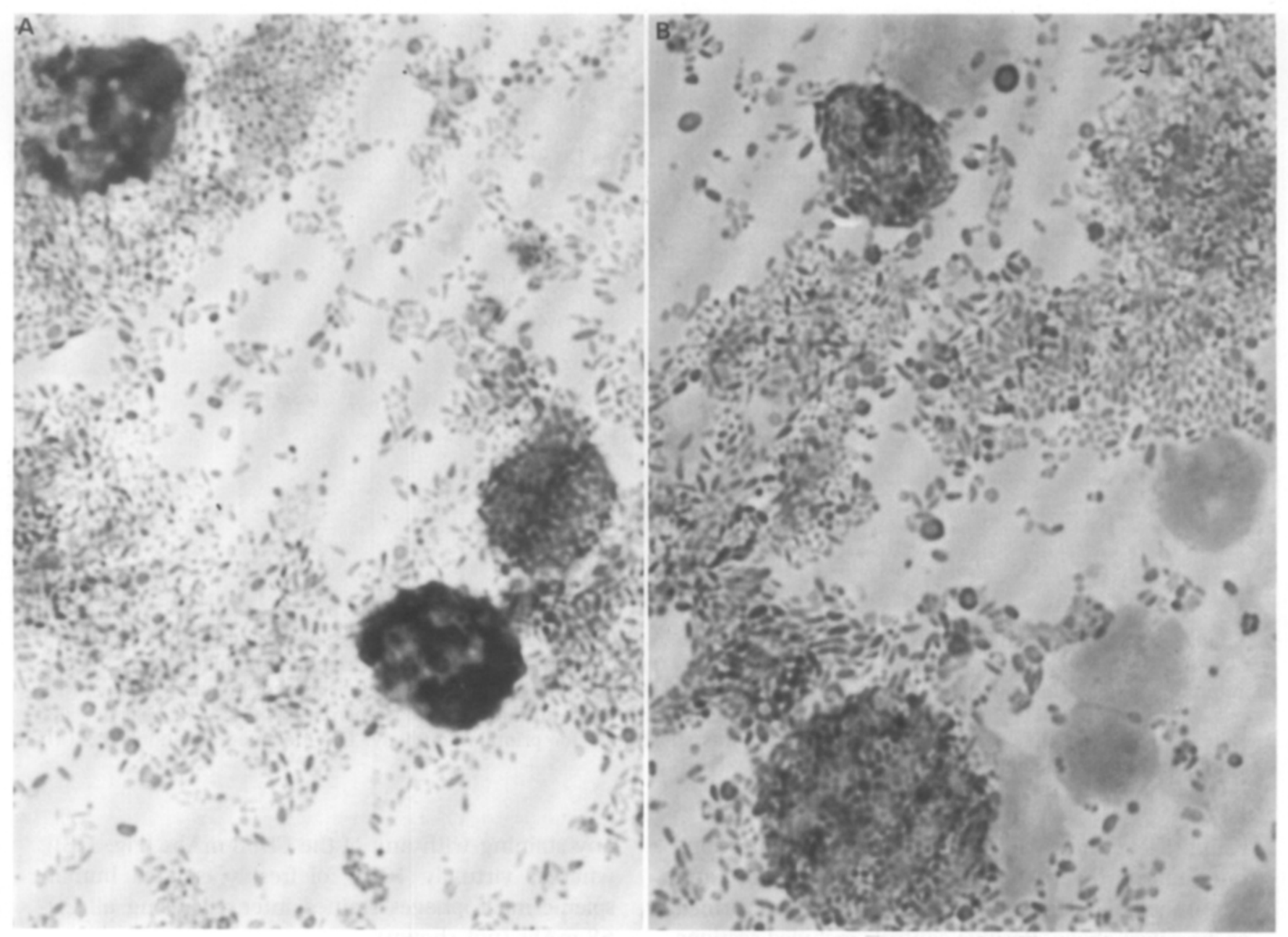

Fig. 3. Cytospin preparation of freshly isolated, pigmented human RPE cells. A, RPE cells demonstrate heavy positive reaction product after immunohistochemical staining using KP1 CD68 mAb. Original magnification: $\times$ 400; immunoalkaline phosphatase-hematoxylin. B. Sister RPE preparation shows no positive stain when normal mouse serum was used as primary antibody. Original magnification: $\times 400$ : immunoalkaline phosphatase-hematoxylin.

$\mathrm{KP} 1$ and EBM11 mAbs were also used for in situ immunohistochemical staining of acetone- and paraformaldehyde-fixed frozen sections of human eyes using immunoalkaline phosphatase and immunoperoxidase techniques. Immunoperoxidase staining was also performed on deparaffinized sections of formalin-fixed human eyes. No detectable staining of the RPE monolayer was present in any of the in situ preparations, but was present in macrophages of normal human spleen which was fixed, sectioned, and stained under the same conditions.

In view of the lack of RPE staining in sections of human eyes, cytospin preparations of freshly isolated human RPE cells were using the immunoalkaline phosphatase technique to yield a red reaction product. Acetone- and paraformaldehyde-fixed RPE cytospin preparation demonstrated intense staining of $5 \%$ of morphologically-intact, melanin-laden RPE cells using CD68 mAbs, KPl and EBMl1 ['Table 1: Fig. 3(A)]. The remaining RPE cells did not contain visible reaction product. Under the same conditions. RPE cytospin preparations incubated using non-immune mouse serum [Fig. 3(B)] or control mAb as primary antibody did not yield detectable stain.

\section{Discussion}

CD68 consists of a cluster of six mAb that selectively bind different epitopes of a $110 \mathrm{kDa}$ glycoprotein that was designated as the CD68 antigen at the Fourth Workshop on Human Leucocyte Differentiation Antigens (Vienna, 1989) (Micklem et al., 1989). Only weakly, if at all, expressed on the surface of cells, CD68 antigen is primarily a cytoplasmic protein composed of 40 and $70 \mathrm{kDa}$ subunits (Micklem et al., 1989) that is concentrated in lysosomes (Kreipe et al., 1987; Parwaresch et al., 1986). The function of CD68 antigen, however, remains unknown.

CD68 antigen has been designated as a macrophage-associated antigen (Micklem et al., 1989) by virtue of its wide distribution in mononuclear phagocytes, including circulating monocytes (Pulford et al., 1990) and macrophages of bone, liver, lung, and spleen (Athanasou et al., 1986; Athanasou and Quinn. 1990; Pulford et al., 1989). The consistent, high reactivity of $\mathrm{CD} 68 \mathrm{mAb}$ with cells of the mononuclear phagocyte system, has led to their use as selective probes for the identification of circulating monocytes and resident tissue macrophages (Kelly 
et al., 1988). CD68 mAb also react with specialized, tissue-based phagocytic cells considered to be part of the mononuclear phagocyte system, namely microglia of the central nervous system (Kelly et al., 1988) and epidermal Langerhans' cells (Sterry et al., 1991).

Nevertheless, recent studies indicate that $\mathrm{CD}$ $68 \mathrm{mAb}$ react, albeit less intensely and less consistently, with cells that are not of mononuclear phagocyte lineage (Pulford et al., 1990). Hematogenous cells such as neutrophils, basophils, mast cells (Horny et al., 1990), megakaryocytes (Athanasou et al., 1986), and lymphocytes as well as certain nonhematogenous cells including hepatocytes and renal glomerular and proximal convoluted tubular cells (Pulford et al., 1990; Franklin et al., 1986) show variable reactivity with the different $\mathrm{mAb}$ in the $\mathrm{CD} 68$ cluster. Cultured and propagated umbilical vascular endothelial, cutaneous melanoma, and vulvar carinoma cell lines also may display different degrees of CD68 immunoreactivity (Pulford et al., 1990). Of these, only hepatocytes, large lymphocytes, and cultured melanoma and vulvar carcinoma cells appear to express strong, consistent immunoreactivity with all CD68 antibodies comparable to that routinely detected in mononuclear phagocytes (Pulford et al.. 1990).

We observed moderate or intense RPE CD68 immunoreactivity in virtually all of the cells in 4-day-old primary cultures with four of the five CD68 mAb used. Marked increases in staining intensity with all five $\mathrm{mAb}$ occurred by first passage and were maintained in these three cell lines and nine other passaged cell lines tested, regardless of passage or degree of confluency. The increased CD68 immunoreactivity we observed in passaged RPE cells may reflect enhanced, cultureinduced RPE phagocytic properties similar to the increased CD68 reactivity of monocytes which differentiate into macrophages in vitro (Parwaresch et al., 1986). Moreover, the granular, perinuclear CD68 staining of RPE cells mimicked the patterns reported for $\mathrm{CD} 68 \mathrm{mAb}$ staining of mononuclear phagocytes (Kreipe et al., 1987: Parwaresch et al., 1986) and those we observed in cultured RPE cells and macrophages following scavenger receptormediated uptake and lysosomal incorporation of fluorescently-labeled, modified low density lipoprotein (Elner et al., 1984; Elner, 1986). Our findings of intense, consistent RPE cell CD68 immunoreactivity, comparable to that seen in mononuclear phagocytes, supports the proposition that RPE cells, like microglia of the brain and Langerhans' cells of the skin, may be specialized, resident macrophage-like cells in the eye at the blood-retina barrier.

In contrast to cultured human RPE cells, intense, constitutive RPE staining with $\mathrm{CD} 68 \mathrm{mAb}$ was present in only a small percentage (5\%) of freshly-isolated, fixed RPE cells in our cytospin preparations (Table I; Fig. 3). Our inability to detect CD68 antigen in frozen or paraffin sections of human eyes may be due to the difficulty in detecting small numbers of positively stained, but thinly-sectioned cells, the small crosssectional area of RPE cells in tissue sections, or the loss of CD68 antigen upon sectioning RPE cells. The lack of $\mathrm{RPE}$ cell reactivity with $24 \mathrm{mAb}$ (Table I), a mAb that had been originally included in the CD68 cluster, provided an excellent negative control since $24 \mathrm{mAb}$ is now known to react with a protein unrelated to $\mathrm{CD} 68$ antigen (Hogg and Selvendran, 1985).

Previous studies have demonstrated several other immunophenotypic and functional similarities between RPE cells and mononuclear phagocytes. Among these are immunoreactive and functional RPE expression of Fc and C3bi receptors (Elner et al., 1981), intercellular adhesion molecule-1 (ICAM-1) receptors, and HLA-DR antigens which may be augmented by IFN- $\gamma$ stimulation (Detrick et al., 1985, 1986; Chan et al., 1986). In spite of the fact that these ligands may be upregulated by IFN- $\gamma$ (Elner et al., 1989; Pavilack et al., 1990; Detrick et al., 1985), we did not observe similar induction of CD68 expression in RPE cells exposed to physiologic doses of rIFN- $\gamma$ for up to $48 \mathrm{hr}$.

The consistent. strong expression of CD68 antigen by cultured human RPE cells may provide an important marker for identification of RPE cells in vitro and to insure purity and uniformity of cultured human RPE cells.

\section{Acknowledgements}

We thank the Michigan Eye Bank and Transplantation Center for human eye tissue and Jean Danforth and Mary Brennan for their technical assistance. This work was supported in part by grants from the Michigan Eye Bank and Transplantation Center and the National Institutes of Health (EY-07003).

\section{References}

Athanasou, N. A., Heryet, A., Quinn, J., Gatter, K. C., Mason, D. Y. and McGee, J. O. (1986). Osteoclasts contain macrophage and megakaryocyte antigens. J. Pathol. 150, 239-46.

Athanasou. N. A. and Quinn, J. (1990). Immunophenotypic differences between osteoclasts and macrophage polykaryons: immunohistological distinction and implications for osteoclast ontogeny and function. J. Clin. Pathol. 43, 997-1003.

Campochiaro, P. A., Jerdan, J. A. and Glaser, B. M. (1986), The extracellular matrix of human retinal pigment epithelial cells in vivo and its synthesis in vitro. Invest Ophthalmol. Vis. Sci. 27, 1615-21.

Chan, C. C., Hooks, J. J., Nussenblatt, R. and Detrick, B. (1986). Expression of Ia antigen on retinal pigment epithelium in experimental autoimmune uveoretinitis. Curr. Eye Res. 5, 325-30.

Detrick, B., Newsome, D. A., Percopo, C. M. and Hooks, J. J. (1985). Class II antigen expression and gamma-interferon modulation of monocytes and retinal pigment epithelial cells from patients with retinitis pigmentosa. Clin. Immunol. Immunopathol. 36. 201-11.

Detrick, B., Rodrigues, M., Chan, C. C., Tso, M. O. and Hooks, J. J. (1986). Expression of HLA-DR antigen on retinal 
pigment epithelial cells in retinitis pigmentosa. $A m$. I. Ophthalmol. 101, 584-90.

Edwards. R. B. (1982). Culture of mammalian retinal pigment epithelium and neural retina. Method Enzymol. 81, 39-43.

Elner, S. G., Davis, H. R. and Elner, V. M. (1984). Acetoacetylated lipoprotein uptake by retinal pigment epithelium (RPE) cells. Invest. Ophthalmol. Vis. Sci. 25 (Suppl.), 248.

Elner, V. M., Schaffner, T., Taylor, K. and Glagov, S. (1981). Immunophagocytic properties of retinal pigment epithelium cells. Science 211, 74-6.

Elner, V. M. (1986). Retinal pigment epithelial cells exhibit macrophage-like features and functions. PhD thesis, University of Chicago.

Elner, V. M., Nielsen, J. C., Elner, S. G. and Franklin, W. A. (1989). Immunophenotypic modulation of cultured human retinal pigment epithelial cells by gammainterferon and phytohemagglutinin-stimulated human T-lymphocytes. Invest. Ophthalmol. Vis. Sci. 30 (Suppl.), 118.

Elner, V. M., Strieter, R. M., Elner, S. G., Baggiolini, M., Lindley, I. and Kunkel, S. L. (1990). Neutrophil chemotactic factor (IL-8) gene expression by cytokine-treated retinal pigment epithelial cells. Am. 1. Pathol. 136, $745-50$.

Franklin, W. A., Mason, D. Y., Pulford, K., Falini. B., Bliss, E. Gatter, K. C., Stein, H., Clarke. L. C. and McGee, J. O. (1986). Immunohistological analysis of human mononuclear phagocytes and dendritic cells by using monoclonal antibodies. Lab. Invest. 54, 322-35.

Hayes, K. C., Lindsey, S., Stephan, Z. F. and Brecker, D. (1989). Retinal pigment epithelium possesses both LDL and scavenger receptor activity. Invest. Ophthalmol. Vis. Sci. 30, 225-32.

Hogg. N. and Selvendran, Y. (1985). An anti-human monocyte/macrophage monoclonal antibody, reacting most strongly with macrophages in lymphoid tissue. Cell. Immunol. 92, 247-53.

Horny, H. P.. Schaumberg-Lever, G., Bolz, S., Geerts, M. L. and Kaiserling. E. (1990). Use of monoclonal antibody KP1 for identifying normal and neoplastic human mast cells. J. Clin. Pathol. 43, 719-22.

Kelly, P. M. A.. Bliss, E. Morton, J. A.. Burns, J. and McGee. J. O. (1988). Monoclonal antibody EBM/11: high cellular specificity for human macrophages. J. Clin. Pathol, 41, 510-5.

Kreipe, H., Radzun, H. J., Parwaresch, M. R., Haislip, A. and Hansmann. H. L. (1987). Ki-M7 monoclonal antibody specific for myelomonocytic cell lineage and macro- phages in humans. J. Histochem. Cytochem. 35.111726.

McLaughlin, B. J.. Tarnowski. B. I. and Shepherd, V. L. (1987). Identification of mannose 6-phosphate and mannose receptors in dystrophic and normal retinal pigment epithelium. Prog. Clin. Biol. Res. 247, 243-57.

McMichael, A. J. (1986). Leucocyte Typing. III. White cell differentiation antigens. Oxford University Press: Oxford.

Micklem, K., Rigney, E., Cordell, J., Simmons, D., Stross, P., Turley, H., Seed, B. and Mason, D. (1989). A human macrophage-associated antigen (CD68) detected by six different monoclonal antibodies. Br. J. Haematol. 73 , 6-11.

Nielsen, J. C., Elner, V. M., Yu, R., Torczynski, E. and Franklin, W. A. (1987). Immunophenotypic characterization of cultured human retinal pigment epithelial (RPE) cells. Invest. Ophthalmol. Vis. Sci. 28 (Suppl.), 381.

Parwaresch, M. R., Radzun, H. J., Kreipe, H., Hansmann, M. L. and Barth, J. (1986). Monocyte-macrophage reactive monoclonal antibody Ki-M6 recognizes an intracytoplasmic antigen. Am. J. Pathol. 125, 141-51.

Pavilack, M. A., Elner, S. G., Feldman, L. E., Todd, R. F. and Elner, V. M. (1990). Human RPE (HRPE) express leukocyte integrins and intercellular adhesion molecules. Invest. Ophthalmol. Vis. Sci. 31 (Suppl.). 372.

Pulford, K. A., Rigney, E. M., Micklem, K. J.. Jones, J. M., Stross, W. P.. Gatter, K. C. and Mason, D. Y. (1989). KP1: a new monoclonal antibody that detects a monocyte/macrophage associated antigen in routinely processed tissue sections. J. Clin. Pathol. 42, 414-21.

Pulford, K. A., Sipos, A., Cordell, J. L.. Stross, W. P. and Mason, D. Y. (1990). Distribution of the CD68 macrophage/myeloid associated antigen. Int. Immunol. 2. 973-80.

Sterry, W., Kunne, N., Weber-Matthiesen, K., Brasch, J. and Mielke, V. (1991). Cell trafficking in positive and negative patch-test reactions: demonstration of a stereotypic migration pathway. J. Invest. Derm. 96, 459-62.

Strieter, R. M., Kunkel, S. L., Showell, H. J., Remick, D. G., Phan, S. H., Ward, P. A. and Marks, R. M. (1989). Endothelial cell gene expression of a neutrophil chemotactic factor by TNF- $\alpha$, LPS, and IL-1 $\beta$. Science 243 , 1467-9.

Strieter, R. M., Chensue, S. W., Basha, M. A., Standiford, T. J., Lynch, J. P., Baggiolini, M. and Kunkel, S. L. (1990). Human alveolar macrophage gene expression of interleukin-8 by tumor necrosis factor-alpha, lipopolysaccharide, and interleukin-1-beta. Am. /. Respir. Cell. Mol. Biol. 2, 321-6. 